\title{
Peningkatan Kemampuan Penguasaan Kosakata Kegiatan Sehari-hari Melalui Penerapan Model Pembelajaran Logan Avenue Problem Solving (LAPS)
}

\author{
Masiyem \\ SDN Kendangsari I/276 Surabaya \\ Jl. Kendangsari Blok S No.26, Kecamatan Tenggilis Mejoyo, Kota Surabaya \\ masiyemm12@gmail.com
}

\begin{abstract}
In fact, the education process for elementary school students really gets a challenge when the online learning implementation policy lasts for months. At least some important stages of development for children to be hampered because of social limitations. One of the stages of development that is hampered in children is language. Language is the initial factor that determines children to be able to communicate with their environment. Unfortunately, not a few parents who escape his attention for this one stage of development. As a result, not infrequently, parents will only realize when their child is 3-5 years old. The purpose of this action research is to determine whether there is an increase in vocabulary mastery skills through the application of the Logan Avenue Problem Solving (LAPS) learning model in Class 1-C students of SDN Kendangsari I/276 and to find out how much the increase in vocabulary mastery skills through the application of the learning model Logan Avenue Problem Solving (LAPS) on them. The application of the learning model is carried out in 2 learning cycles, each of which uses 4 hours of lessons. Data was collected by means of documentation, observation, and tests, while the data analysis technique in this study used qualitative data analysis and quantitative data analysis. Based on the results of data analysis and discussion, it can be concluded that there is an increase in vocabulary mastery skills through the application of the Logan Avenue Problem Solving (LAPS) learning model in Class 1C students of SDN Kendangsari I/276. The increase in vocabulary mastery skills through the application of the Logan Avenue Problem Solving (LAPS) learning model in Class 1-C students of SDN Kendangsari I/276 by $21 \%$.
\end{abstract}

Keywords: Ability, Vocabulary Mastery, Learning Model, LAPS

\begin{abstract}
Abstrak
Sejatinya proses pendidikan bagi siswa Sekolah Dasar benar-benar mendapatkan tantangan saat kebijakan pelaksanaan pembelajaran secara daring berlangsung selama berbulan-bulan. Setidaknya beberapa tahap penting perkembangan bagi anak menjadi terhambat karena keterbatasan bersosial. Salah satu tahapan perkembangan yang terhambat pada anak adalah bahasa. Bahasa merupakan faktor awal yang menentukan anak untuk dapat berkomunikasi kepada lingkungannya. Sayangnya, tidak sedikit orang tua yang luput perhatiannya untuk tahapan perkembangan yang satu ini. Alhasil, tak jarang, orang tua baru akan tersadar ketika anaknya sudah menginjak usia 3-5 tahun. Tujuan penelitian tindakan ini adalah untuk mengetahui ada tidaknya peningkatan kemampuan penguasaan kosakata melalui penerapan model pembelajaran Logan Avenue Problem Solving (LAPS) pada siswa Kelas 1-C SDN Kendangsari I/276 dan untuk mengetahui seberapa besar peningkatan kemampuan penguasaan kosakata melalui penerapan model pembelajaran Logan Avenue Problem Solving (LAPS) pada mereka. Penerapan model pembelajaran tersebut dilakukan pada 2 siklus pembelajaran yang masing-masing menggunakan 4 jam pelajaran. Pengumpulan data dilakukan dengan teknik dokumentasi, observasi dan tes, sedangkan teknik analisa data dalam penelitian ini penulis menggunakan analisis data kualitatif dan analisis data kuantitatif. Berdasarkan hasil analisis data dan pembahasan dapat disimpulkan bahwa ada peningkatan kemampuan penguasaan kosakata melalui penerapan model pembelajaran Logan Avenue Problem Solving (LAPS) pada siswa Kelas 1-C SDN Kendangsari I/276. Peningkatan kemampuan penguasaan kosakata melalui penerapan model pembelajaran Logan Avenue Problem Solving (LAPS) pada siswa Kelas 1-C SDN Kendangsari $\mathrm{I} / 276$ sebesar $21 \%$.
\end{abstract}

Kata kunci: Kemampuan, Penguasaan Kosakata, Model Pembelajaran, LAPS

Copyright (c) 2021 Masiyem

Corresponding author: Nursanti Rajagukguk

Email Address: masiyemm12@gmail.com (Jl. Kendangsari Blok S No.26, Kec. Tenggilis Mejoyo, Kota Surabaya)

Received 09 September 2021, Accepted 06 October 2021, Published 10 November 2021 


\section{PENDAHULUAN}

Sejatinya proses pendidikan bagi siswa Sekolah Dasar benar-benar mendapatkan tantangan saat kebijakan pelaksanaan pembelajaran secara daring berlangsung selama berbulan-bulan. Setidaknya beberapa tahap penting perkembangan bagi anak menjadi terhambat karena keterbatasan bersosial. Salah satu tahapan perkembangan yang terhambat pada anak adalah bahasa. Bahasa merupakan faktor awal yang menentukan anak untuk dapat berkomunikasi kepada lingkungannya. Sayangnya, tidak sedikit orang tua yang luput perhatiannya untuk tahapan perkembangan yang satu ini. Alhasil, tak jarang, orang tua baru akan tersadar ketika anaknya sudah menginjak usia 3-5 tahun.

Para peneliti percaya bahwa perkembangan bahasa anak dimulai sejak anak masih di dalam kandungan (Santrock, 2014). Ketika dalam kandungan, anak memiliki kemampuan untuk mengidentifikasi suara dan irama percakapan dari sang ibu, meskipun kemampuan verbalnya belum berkembang saat itu. Kemampuan ini mampu akan bertahan sampai anak dilahirkan dan menginjak usia empat bulan. Sementara itu, perkembangan kemampuan ekspresi verbal yang pertama ali dapat dilakukan oleh anak adalah menangis. Melalui tangisan, anak mulai berekspresi atas apa yang dirasakan untuk mendapatkan perhatian dari orang tuanya misalnya seorang anak akan menangis ketika mereka merasa lapar, haus atau merasa tidak nyaman. Kemudian, kemampuan ini akan mulai berkembang.

Disadari atau tidak untuk memperoleh keterampilan berbahasa yang tepat, penguasaan kosakata sangat menentukan. Sebagaimana yang dikatakan Judd (dalam Buchari, 1995), bahwa kosakata merupakan langkah awal yang harus dipandang sebagai sumber untuk dapat berkomunikasi dengan baik.

Menurut Sanjaya (2010) penelitian tentang penggunaan kosakata dalam menulis teks, baik teks ilmiah maupun fiksi, serta surat, baik resmi maupun pribadi, telah dilakukan dari masa ke masa. Begitu banyak penelitian dilakukan untuk mencari di mana kelemahan dan apa inti persoalan sehingga mahasiswa begitu banyak yang gagal menyelesaikan karya tulis dan gagal dalam menempuh mata kuliah menulis. Hasil penelitian menunjukkan bahwa ketidakberhasilan mahasiswa banyak disebabkan oleh ketidakmampuan mahasiswa dalam memilih kata yang tepat. Di samping itu, mahasiswa juga salah memilih kosakata dengan ejaan yang tidak tepat.

Berdasarkan uraian di atas, maka penulis terdorong untuk mengangkat permasalahan tersebut dalam penelitian tindakan yang berjudul "Peningkatan Kemampuan Penguasaan Kosakata Kegiatan Sehari-hari melalui Penerapan Model Pembelajaran Logan Avenue Problem Solving (LAPS) pada Siswa Kelas 1C SDN Kendangsari I/276 Semester Gasal Tahun Pelajaran 2021/2021”. Tujuan penelitian ini adalah (1) untuk mengetahui ada tidaknya peningkatan kemampuan penguasaan kosakata melalui penerapan model pembelajaran Logan Avenue Problem Solving (LAPS) pada siswa Kelas 1C SDN Kendangsari I/276., dan (2) untuk mengetahui seberapa besar peningkatan kemampuan penguasaan kosakata melalui penerapan model pembelajaran Logan Avenue Problem Solving (LAPS) pada siswa Kelas 1C SDN Kendangsari I/276.

\section{Kemampuan Berbahasa}

Pentingnya keterampilan berbahasa bukan saja bagi guru, tetapi juga bagi siswa sebagai subjek 
dan objek didik. Dalam kehidupan sehari-hari, manusia dituntut terampil berbicara. Hal ini sejalan dengan pernyataan yang dilontarkan oleh Suyoto (2003:32) bahwa seseorang yang terampil berbicara cenderung berani tampil di masyarakat. Dia juga cenderung memiliki keberanian untuk tampil menjadi pemimpin pada kelompoknya.

Berbicara adalah kemampuan mengucapkan bunyi-bunyi artikulasi atau kata-kata untuk mengekspresikan, menyatakan serta menyampaikan pikiran, gagasan dan perasaan (Tarigan, 1993:15). Selain itu, Tarigan juga berpendapat bahwa berbicara adalah keterampilan menyampaikan pesan melalui bahasa lisan kepada orang lain. Berbicara merupakan suatu keterampilan, dan keterampilan tidak akan berkembang kalau tidak dilatih secara terus menerus. Oleh karena itu, kepandaian berbicara tidak akan dikuasai dengan baik tanpa dilatih. Apabila selalu dilatih, keterampilan berbahasa tentu akan semakin baik. Sebaliknya, kalau malu, ragu, atau takut salah dalam berlatih berbicara, niscaya kepandaian atau keterampilan berbahasa itu semakin jauh dari penguasaan. Keterampilan berbahasa lebih mudah dikembangkan apabila siswa-siswa memperoleh kesempatan untuk mengkomunikasikan sesuatu secara alami kepada orang lain, dalam kesempatan-kesempatan yang bersifat informal. Selama kegiatan belajar di sekolah, guru menciptakan berbagai lapangan pengalaman yang memungkinkan siswa-siswa mengembangkan kemampuan berbahasa.

Keterampilan berbahasa harus dikuasai oleh para siswa Sekolah Dasar karena keterampilan ini secara langsung berkaitan dengan seluruh proses belajar siswa di Sekolah Dasar. Keberhasilan belajar siswa dalam mengikuti proses kegiatan belajar-mengajar di sekolah sangat ditentukan oleh penguasaan kemampuan berbahasa mereka. Siswa yang tidak mampu berbicara dengan baik dan benar akan mengalami kesulitan dalam mengikuti kegiatan pembelajaran untuk semua mata pelajaran.

Seperti yang diungkapkan Galda (dalam Supriyadi, 2005: 178) keterampilan berbahasa di SD merupakan inti dari proses pembelajaran bahasa di sekolah, karena dengan pembelajaran berbicara siswa dapat berkomunikasi di dalam maupun di luar kelas sesuai dengan perkembangan jiwanya. Pendapat tersebut juga didukung oleh Farris (dalam Supriyadi, 2005: 179) yang menyatakan bahwa pembelajaran keterampilan berbahasa penting diajarkan karena dengan keterampilan itu seorang siswa akan mampu mengembangkan kemampuan berpikir, membaca, menulis, dan menyimak. Kemampuan berpikir tersebut akan terlatih ketika mereka mengorganisasikan, mengonsepkan, dan menyederhanakan pikiran, perasaan, dan ide kepada orang lain secara lisan.

Dalam Ketrampilan Berbahasa dalam proses pembelajaran memiliki faktor penunjang yang mampu meningkatkan Ketrampilan Berbahasa. Namun, memanglah dipastikan akan mengalami kendala yang berarti dalam ketercapainnya. Berikut faktor penunjang dan faktor penghambat dalam peningkatan Ketrampilan Berbahasa siswa Sekolah Dasar:

1. Faktor penunjang ketrampilan berbahasa, meliputi; a) ketepatan ucapan, b) penempatan tekanan nada, sendi atau durasi yang sesuai, c) pilihan kata, d) gerak-gerik dan mimik yang tepat, e) kenyaringan suara, f) kelancaran, g) relevansi dan penalaran, h) penguasaan topik.

2. Faktor penghambat ketrampilan berbahasa, meliputi: a) faktor fisik, b) faktor media, dan c) faktor 
Peningkatan Kemampuan Penguasaan Kosakata Kegiatan Sehari-hari Melalui Penerapan Model Pembelajaran Logan Avenue Problem Solving (LAPS), Masiyem

psikologis

\section{Pengembangan Kosakata}

Ada beberapa pengertian kosakata yang dikemukakan oleh beberapa ahli bahasa. Menurut Mukidi (1994: 43) kosakata sama dengan leksikon. Di sini leksikon diartikan sebagai perbendaharaan kata dalam suatu bahasa. Leksikon merupakan komponen bahasa yang memuat semua informasi tentang makna dan pemakaian kata dalam suatu bahasa. Dalam Kamus Besar Bahasa Indonesia (2000: 597) kosakata diartikan sebagai perbendaharaan kata. Kridalaksana (1993: 127) menjelaskan bahwa kosakata sama dengan leksikon, sedangkan yang dimaksud dengan leksikon adalah: (1) komponen bahasa yang memuat secara informatif tentang makna dan pemakaian kata dalam suatu bahasa, (2) kekayaan kosakata yang disusun seseorang pembicara atau penulis, (3) daftar kata yang disusun dengan penjelasan singkat dan praktis.

Berdasarkan pendapat-pendapat di atas dapat disimpulkan bahwa kosakata merupakan sejumlah kata yang dimiliki oleh suatu bahasa. Dengan demikian, penguasaan kosakata dapat diartikan sebagai kemampuan seseorang dalam menguasai dan mempergunakan kata-kata atau perbendaharaan kata yang terdapat dalam suatu bahasa. Menurut Darmiyati Zuchdi (1995: 3-7) penguasaan kosakata adalah kemampuan seseorang untuk mengenal, memahami, dan menggunakan kata-kata dengan baik dan benar, dengan mendengar, berbicara, membaca, dan menulis. Mengenal kata adalah memperoleh kata-kata baru dari hasil mendengarkan atau dari hasil membaca. Selanjutnya, hakikat memahami katakata adalah memperoleh kosakata baru, mengerti kata dan artinya serta memahami keterkaitan kata dan konsep yang diawali kata-kata tersebut. Kamus Besar Bahasa Indonesia (2000: 534) memberikan batasan penguasaan kosakata sebagai pemahaman atau kesanggupan untuk menggunakan sesuatu hal (sejumlah kekayaan kata yang terdapat dalam suatu bahasa).

Menurut Djiwandono (2008) dalam kegiatan berkomunikasi kosakata merupakan unsur yang amat penting. Makna suatu wacana sebagai bentuk penggunaan bahasa sebagian besar ditentukan oleh kosakata yang digunakan dalam pengungkapannya. Dengan demikian, apabila seorang anak kurang memiliki kemampuan dalam menguasai kosakata, anak tersebut akan mengalami kesulitan dalam memahami suatu bahasa. Nurgiyantoro B. (2001: 209) menyatakan bahwa untuk tes penguasaan kosakata tingkatan kognitif yang dipakai sampai pada tingkat analisis (C4). Berdasarkan pendapat tersebut tes penguasaan kosakata dalam penelitian ini menggunakan empat tingkatan yaitu tingkat ingatan/pengetahuan (C1), tingkat pemahaman (C2), tingkat aplikasi (C3), dan tingkat analasis (C4). Tes kosakata tingkat kognitif yang tinggi (C5 dan C6) tidak digunakan dalam penelitian ini karena tes dengan tingkat kognitif tersebut menuntut kemampuan yang lebih dalam dan sekaligus dapat menilai proses berpikir. Selain itu, tes kosakata tingkat C5 dan C6 lebih tepat apabila digunakan untuk tes bentuk esai

\section{Model Pembelajaran Logan Avenue Problem Solving (LAPS)}

Model pembelajaran adalah suatu disain yang menggambarkan proses rincian dan penciptaan 
situasi lingkungan yang memungkinkan siswa berinteraksi sehingga terjadi perubahan atau perkembangan pada diri siswa. Model pembelajaran merupakan suatu rencana atau pola yang digunakan dalam menyusun kurikulum, mengatur materi pelajaran, dan memberi petunjuk kepada pengajar di kelas dalam setting pengajaran atau dalam setting lainnya. Model pembelajaran juga dapat didefinisikan sebagai kerangka konseptual yang menggambarkan prosedur sistematik dalam pengorganisasian pengalaman belajar untuk mencapai tujuan belajar tertentu. Model pembelajaran ditunjukan secara jelas kegiatan-kegiatan apa saja yang harus dilakukan oleh guru atau siswa, bagaimana urutan kegiatan tersebut dan tugas-tugas khusus apa yang perlu dilakukan oleh siswa. Jadi, dapat disimpulkan bahwa pembelajaran tidak semata-mata menyampaikan materi sesuai dengan target kurikulum, tanpa memperhatikan kondisi siswa, tetapi juga terkait dengan unsur manusiawi, material, fasilitas, perlengkapan, dan prosedur yang saling mempengaruhi demi mencapai tujuan pembelajaran.

Model pembelajaran Logan Avenue Problem Solving adalah rangkaian pertanyaan yang bersifat tuntunan dalam solusi masalah. LAPS (Logan Avenue Problem Solving) biasanya menggunkan kata tanya apa masalahnya, adakah alternatif, apakah bermanfaat, apakah solusinya dan bagaimana sebaiknya mengerjakannya. Heuristik adalah suatu penuntunan berupa pertanyaan yang diperlukan untuk menyelasaikan suatu maslah. Heuristik berfungsi untuk mengarahkan pemecahan masalah siswa yang diberikan.

Dalam Kamus Istilah Pendidikan dan Umun, Heuristis adalah jalan berpikir menurut suatu cara terbimbing untuk memecahkan suatu masalah. Heuristic Method adalah suatu metode pendidikan, yang terutama berlaku, walaupun tidak terbatas pada pengajaran science, yang asasnya ialah mengatur pekerjaan sedemikian rupa sehingga murid atau anak didik menemukan sendiri hukum-hukum dan asas, dan bukan mempelajarinya informasi yang diberikan oleh guru lewat pihak kedua.

Strategi pembelajaran heuristik merupakan strategi dengan pengorganisasian materi yang tidak mengikuti urutan regular dan juga tidak seragam tetapi mengikuti petunjuk praktis yang lepas-lepas. Kondisi saling lepas menekankan bahwa koleksi strategi, petunjuk praktis, bimbingan atau saran yang digunakan dalam memecahkan masalah tidak tetap, baik banyaknya maupun urutannya. Pelaku memiliki kebebasan untuk menetapkan dari mana harus memulai proses dan kemudian menentukan proses apa yang mesti dilakukan berikutnya.

Kompleksitas proses heuristik sebagai sebuah system sangat dinamis dan operasi-operasi di dalamnya sangat terbuka terhadap perubahan. Banathy menyatakan bahwa sistem heuristik mampu menyusun tujuannya di bawah petunjuk kebijakan yang lebih luas, sangat pluralistik, terbuka untuk perubahan dan bahkan sering memulai perubahan serta memiliki kompleksitas yang sangat dinamis. Strategi pembelajaran heuristik ada empat pendekatan yang sering digunakan dalam strategi pembelajaran heuristic, yaitu pendekatan bekerja mundur, pendekatan analogi, pendekatan memecah tujuan, dan pendekatan memperkecil perbedaan.

Prinsip-prinsip penerapannya adalah sebagai berikut:

1. Memahami masalah (Understanding the problem) 
2. Merencanakan pemecahannya (Devising a plan).

3. Menyalesaikan masalah (Carrying out the plan).

4. Memeriksa kembali hasil yang diperoleh (Looking back)

Terkadang langkah keempat kurang diperhatikan oleh siswa. Padahal langkah ini untuk menguji ketetapan hasil yang diperoleh sehingga dapat digunakan sebagai dasar penyelesaian masalah selanjutnya. Dengan demikian penggunaan model pembelajaran Logan Avenue Problem Solving (LAPS) dalam penyelesaian soal-soal urean sangat relevan dan perlu ditekankan bagi para siswa sehingga terlatih untuk menyelesaiakan persoalan dengaan berpikir kritis secara urut dan sistematis.

Adapun langkah-langkah pembelajaran yang akan di terapkan dalam mnggunakan model Logan Avenue Problem Solving (LAPS) sebagai berikut:

1. Guru menyajikan materi pelajaran disini yang digunakan materi tentang pelajaran tematik.

2. Guru membagi siswa dalam kelompok-kelompok secara acak yang masing-masing terdiri dari 4-5 anggota.

3. Guru membagikan Lembar Kerja Kelompok (LKK) yang harus dipecahkan.

4. Guru menyuruh setiap siswa menetapkan jawaban sementara dari soalsoal LKK tersebut dari data yang mereka peroleh.

5. Guru menyuruh siswa menguji kembali jawaban sementara mereka dengan teman kelompoknya untuk memperoleh jawaban yang paling benar.

6. Guru menyuruh siswa menarik kesimpulan, yaitu siswa harus sampai pada kesimpulan tentang jawaban terakhir dari soal-soal LKK dan menuliskannya untuk mengerjakan pada lembar jawaban yang telah disediakan.

7. Guru membantu siswa melakukan refleksi dan evaluasi terhadap hasil diskusi dan proses-proses siswa gunakan dengan menunjuk secara acak beberapa siswa mewakili kelompoknya untuk mengerjakan di papan tulis kemudian dibahas bersama.

8. Menarik kesimpulan, artinya siswa harus sampai pada kesimpulan terakhir tentang jawaban dari masalah tadi.

Pada hakekatnya implementasi model pembelajaran Logan Avenue Problem Solving (LAPS) tidak hanya memahami dan menguasai apa dan bagaimana suatu terjadi, tetapi juga memberi pemahaman dan penguasaan tentang mengapa hal tersebut bisa terjadi. Tujuan akhir pembelajaran adalah menghasilkan siswa yang memiliki pengetahuan dan keterampilan dalam memecahkan masalah yang dihadapi kelak dimasyarakat.

\section{METODE}

\section{Setting Penelitian}

Jenis penelitian yang dilakukan oleh peneliti yaitu penelitian tindakan kelas, yang lazim disebut PTK. Dengan demikian, penelitian ini sifatnya berbasis kelas, karena dilakukan dengan melibatkan komponen yang terdapat di dalam proses belajar mengajar di dalam kelas, materi pelajaran, dan metode 
pembelajaran. Tujuan dari penelitian ini tidak lain adalah untuk memperbaiki pembelajaran menulis dan meningkatkan kemampuan Menulis Cerita Sederhana siswa melalui metode latihan terbimbing dengan media teks lagu. Diharapkan dari penelitian ini hasil belajar dapat lebih maksimal.

Empat tahapan digunakan secara sistematis dalam proses penelitian ini, dan diterapkan dalam dua siklus, yaitu proses tindakan siklus I dan proses tindakan siklus II. Namun dalam hal ini, peneliti memerlukan kajian awal berupa renungan atau refleksi awal sebagai studi pendahuluan sebelum melakukan perencanaan penelitian. Hal ini untuk mengetahui semua gejala atau informasi tentang situasi-situasi yang relevan dengan topik penelitian.

\section{Subyek Penelitian}

Penelitian ini dilaksanakan oleh penulis di SD Negeri Kendangsari I/276 dengan alamat Jl. Kendangsari Blok S No. 26 Kecamatan Tenggilis Mejoyo Kota Surabaya. Pelaksanaan penelitian dan perbaikan dijadwalkan oleh penulis dengan jadwal sebagai berikut:

Tabel 1. Waktu Pelaksanaan

\begin{tabular}{|c|c|c|}
\hline No & Siklus & Waktu \\
\hline 1 & Siklus 1 & Selasa, 1 dan 8 September 2021 \\
\hline 2 & Siklus 2 & Selasa, 15 dan 22 September 2021 \\
\hline
\end{tabular}

Kelas yang dijadikan obyek perbaikan dan penelitian adalah kelas 1-C dengan jumlah 32 siswa.

\section{Teknik Pengumpulan Data}

Adapun teknik pengumpulan data yang penulis gunakan dalam penelitian ini adalah teknik nontes dan teknik tes. Teknik nontes alat penilaian yang dipergunakan untuk mendapatkan informasi tentang keadaan di tertes (testi, tercoba, inggris testee) tanpa dengan alat tes. Teknik nontes diperlukan untuk mendapatkan data yang tidak, atau paling tidak secara langsung, berkaitan dengan laku kognitif. Teknik ini diterapkan melalui kegiatan observasi dan pengumpulan dokumentasi.

Adapun teknik tes adalah teknik yang dilakukan untuk memperoleh data dengan menggunakan tes. Tes dilakukan sebanyak dua kali, yaitu pada siklus I dan pada siklus II. Materi tes dibuat penulis dengan memperhatikan buku panduan mata pelajaran Matematika. Tes digunakan untuk mengukur dasar dan pencapaian prestasi (Arikunto, 2002:196). Hasil tes siklus I dianalisis tersebut dapat diketahui kelemahan siswa, yang selanjutnya sebagai dasar untuk melengkapi siklus II. Hasil siklus II dianalisis sehingga dapat diketahui peningkatan hasil belajar.

\section{Validasi Data}

Uji instrumen ini menggunakan validitas isi dan permukaan. Validitas isi adalah derajat tes yang menggambarkan esensi, topik-topik, dan ruang lingkup tes yang dirancang untuk pengukuran, (Sevilla dalam Hardani 2006:39). Validitas isi dilakukan dengan menyesuaikan aspek keterampilan Menulis Cerita Sederhana berdasarkan landasan teori yang ada.

Validitas permukaan (paras) adalah tipe validitas yang berkaitan dengan tipe tes. Tipe validitas ini tidak didukung oleh bukti-bukti bahwa tes tersebut dapat mengukur sesuatu (Sevilla dalam Hardani 
2006:39). Validitas permukaan dilakukan dengan cara dikonsultasikan dengan dosen pembimbing dan guru, sehingga dari pendapat mereka dapat disepakati bahwa instrumen yang akan digunakan dalam penelitian sudah valid.

\section{Teknik Analisa Data}

Dalam penelitian ini penulis menggunakan analisis data kualitatif dan analisis data kuantitatif. Teknik analisa data menggunakan teknik analisis kuantitatif dan kualitatif. Analisis data kualitatif pada penelitian ini diperoleh dari hasil observasi yang dilakukan oleh penulis yang memuat gambaran tingkat pengetahuansiswa terhadap suatu mata pelajaran, aktivitas dan antusiasme siswa saat mengikuti pelajaran setiap siklus.

Analisis data kuantitatif diperoleh dari hasil tes siswa yang bertujuan untuk mengetahui pengetahuansiswa tentang materi pelajaran dari setiap siklus, di mana siswa secara individu telah belajar tuntas atau berhasil apabila sekurang-kurangnya mendapat nilai 70. Standar penentuan ketuntasan belajar siswa menurut Sudjana (2006:109) sebagai berikut:

$$
\mathrm{P}=\sum_{\mathrm{N}} \mathrm{f} \times 100 \%
$$

Keterangan:

P : $\quad$ Persentase ketuntasan secara individu.

$\sum \mathrm{f} \quad$ : Jumlah nilai yang diperoleh siswa.

$\mathrm{N} \quad$ : Nilai maksimal.

Sedangkan untuk mencari persentase ketuntasan secara klasikal menggunakan rumus:

$$
\mathrm{P}=\underset{\mathrm{N}}{\sum \mathrm{n}} \times 100 \%
$$

Keterangan:

P : : Persentase ketuntasan belajar secara klasikal.

$\sum \mathrm{n} \quad$ : Jumlah siswa yang mendapat nilai $\geq 70$.

$\mathrm{N} \quad$ : Jumlah siswa seluruhnya.

Data pengamatan dianalisis dengan menghitung rata-rata pada setiap siklus yang dilaksanakan, selanjutnya nilai rata-rata tersebut diklasifikasikan dengan kriteria sebagai berikut:

$\begin{array}{ll}76-100 & \text { : Sangat baik } \\ 66-75 & : \text { Baik } \\ 46-65 & \text { : Cukup } \\ 0-45 & \text { : Kurang }\end{array}$

\section{Indikator Kinerja}

Indikator kinerja dalam penelitian ini sebagaimana terinci dalam tabel berikut:

Tabel 2. Indikator Kinerja

No $\quad$ Indikator yang Diukur




\begin{tabular}{|c|l|}
\hline 1 & Menggunakan kata-kata yang banyak/tidak langsung (tidak to the point) \\
\hline 2 & Mengubah kata-kata baru agar lebih dikenal (penyerapan kata asing) \\
\hline 3 & Menggunakan kata-kata yang umum atau sudah dikenal \\
\hline 4 & $\begin{array}{l}\text { Menggunakan ekspresi atau alih kode, contoh: menggunakan bahasa yang sopan pada } \\
\text { orang yang lebih tua }\end{array}$ \\
\hline 5 & Menggunakan gerak tubuh atau mimik untuk meyakinkan maksud yang kita inginkan \\
\hline
\end{tabular}

\section{HASIL DAN DISKUSI}

\section{Deskripsi Siklus I}

Pembelajaran pada siklus I dilaksanakan dalam waktu 2 × 3 × 25 menit. Pertemuan siklus I direncanakan pada hari Selasa, tanggal 1 dan 8 September 2021, jam pelajaran 1 sampai dengan 3.

Kegiatan pembelajaran pada siklus I meliputi kegiatan awal, kegiatan inti dan kegiatan akhir. Kegiatan pembelajaran yang dilakukan ini sesuai dengan langkah-langkah model pembelajaran Logan Avenue Problem Solving (LAPS) sebagai berikut:

1. Guru menyajikan materi pelajaran disini yang digunakan materi tentang pelajaran tematik.

2. Guru membagi siswa dalam kelompok-kelompok secara acak yang masing-masing terdiri dari 4-5 anggota.

3. Guru membagikan Lembar Kerja Kelompok (LKK) yang harus dipecahkan.

4. Guru menyuruh setiap siswa menetapkan jawaban sementara dari soalsoal LKK tersebut dari data yang mereka peroleh.

5. Guru menyuruh siswa menguji kembali jawaban sementara mereka dengan teman kelompoknya untuk memperoleh jawaban yang paling benar.

6. Guru menyuruh siswa menarik kesimpulan, yaitu siswa harus sampai pada kesimpulan tentang jawaban terakhir dari soal-soal LKK dan menuliskannya untuk mengerjakan pada lembar jawaban yang telah disediakan.

7. Guru membantu siswa melakukan refleksi dan evaluasi terhadap hasil diskusi dan proses-proses siswa gunakan dengan menunjuk secara acak beberapa siswa mewakili kelompoknya untuk mengerjakan di papan tulis kemudian dibahas bersama.

8. Menarik kesimpulan, artinya siswa harus sampai pada kesimpulan terakhir tentang jawaban dari masalah tadi.

Penilaian observer tentang Aktivitas Guru pada Siklus I termasuk dalam kategori baik. Hal ini terlihat pada tahap pembelajaran kegiatan awal. Hal ini dipengaruhi oleh kemampuan guru dalam memotivasi siswa. Pada tahap kegiatan inti guru masih belum bisa melakukan improvisasi dan belum mengerti tentang langkah-langkah penyelesaian dalam pemecahan. Maka dari tinjauan ini, observer menyimpulkan bahwa pada tahap kegiatan Siklus I, tampaknya guru masih perlu bimbingan dalam hal mengimprovisasi langkah demi langkah dari metode yang digunakan.

Berdasarkan hasil analisa pada hasil belajar siswa dapat disimpulkan bahwa pada siklus I ratarata nilai Kemampuan Penguasaan Kosakata Kegiatan Sehari-hari siswa adalah 13,60 atau 68\%. Hal ini 
bila diinterpretasikan ke dalam tabel interpretasi dengan rata-rata 2,72 dari rata-rata skor 13,77 maka termasuk ke dalam kategori cukup. Adapun ketuntasan klasikal pada siklus I sebesar 50\% dengan kategori cukup. Selain bagi siswa, model pembelajaran Logan Avenue Problem Solving (LAPS) ini merupakan hal yang baru bagi penulis sehingga sempat agak bingung bagaimana cara menjelaskan aturan pelaksanaannya pada siswa. Di samping itu, penulis sempat meragukan apakah dengan model dan metode pembelajaran ini kemampuan berbahasa siswa berubah

\section{Deskripsi Siklus II}

Pembelajaran pada siklus I dilaksanakan dalam waktu 2 × 3 × 25 menit. Pertemuan siklus I direncanakan pada hari Selasa, tanggal 15 dan 22 September 2021, jam pelajaran 1 sampai dengan 3.

Kegiatan pembelajaran pada siklus I meliputi kegiatan awal, kegiatan inti dan kegiatan akhir. Kegiatan pembelajaran yang dilakukan ini sesuai dengan langkah-langkah model pembelajaran Logan Avenue Problem Solving (LAPS) sebagai berikut:

1. Guru menyajikan materi pelajaran disini yang digunakan materi tentang pelajaran tematik.

2. Guru membagi siswa dalam kelompok-kelompok secara acak yang masing-masing terdiri dari 4-5 anggota.

3. Guru membagikan Lembar Kerja Kelompok (LKK) yang harus dipecahkan.

4. Guru menyuruh setiap siswa menetapkan jawaban sementara dari soalsoal LKK tersebut dari data yang mereka peroleh.

5. Guru menyuruh siswa menguji kembali jawaban sementara mereka dengan teman kelompoknya untuk memperoleh jawaban yang paling benar.

6. Guru menyuruh siswa menarik kesimpulan, yaitu siswa harus sampai pada kesimpulan tentang jawaban terakhir dari soal-soal LKK dan menuliskannya untuk mengerjakan pada lembar jawaban yang telah disediakan.

7. Guru membantu siswa melakukan refleksi dan evaluasi terhadap hasil diskusi dan proses-proses siswa gunakan dengan menunjuk secara acak beberapa siswa mewakili kelompoknya untuk mengerjakan di papan tulis kemudian dibahas bersama.

8. Menarik kesimpulan, artinya siswa harus sampai pada kesimpulan terakhir tentang jawaban dari masalah tadi.

Penilaian observer tentang Aktivitas Guru pada Siklus II termasuk dalam kategori sangat baik. Hal ini terlihat pada tahap pembelajaran kegiatan awal. Hal ini dipengaruhi oleh kepandaian guru dalam memotivasi siswa. Pada tahap kegiatan inti guru telah berhasil melakukan improvisasi pada langkahlangkah penyelesaian. Maka dari tinjauan ini, observer menyimpulkan bahwa pada tahap kegiatan Siklus II secara global berjalan dengan lancar. Berdasarkan hasil analisa terhadap hasil belajar siswa dapat disimpulkan bahwa pada siklus II rata-rata nilai Kemampuan Penguasaan Kosakata Kegiatan Sehari-hari siswa adalah 14,92 atau $75 \%$. Hal ini bila diinterpretasikan ke dalam tabel interpretasi dengan rata-rata 2,99 dari rata-rata skor 14,92 maka termasuk ke dalam kategori baik. Adapun ketuntasan klasikal pada siklus II sebesar $81 \%$ dengan kategori sangat baik. 
Selain bagi siswa, model pembelajaran Logan Avenue Problem Solving (LAPS) ini merupakan hal yang menyenangkan bagi penulis sehingga pembelajaran menjadi hidup dan aktivitas siswa dalam belajar semakin meningkat. Model pembelajaran Logan Avenue Problem Solving (LAPS) ini harus dilaksanakan secara berkesinambungan sebagai upaya pembiasaan bagi siswa.

\section{Diskusi}

Dengan demikian penerapan model pembelajaran Logan Avenue Problem Solving (LAPS) memiliki efektifitas untuk meningkatkan nilai kemampuan penguasaan kosakata kegiatan sehari-hari siswa. Hal ini terlihat dari tanjakan persentase kemampuan penguasaan kosakata siswa dari sebelum diterapkan metode pembelajaran ini yang hanya 54\% menjadi $68 \%$ pada siklus I dan $75 \%$ pada siklus II. Peningkatan kemampuan sebesar $21 \%$ dari dua siklus ini jika ditelusuri lebih dalam adalah karena adanya faktor motivasi dari dalam diri siswa itu sendiri, apakah mereka mau menunjukkan seluruh kemampuan penguasaan kosakata yang menjadi indikator penelitian sepenuh hati mereka atau tidak. Model dan metode pembelajaran yang diterapkan hanyalah faktor stimulus untuk memunculkan pembiasaan pada diri siswa.

Anggapan penulis ini tentu saja masih perlu dibuktikan dengan penelitian tindakan kelas lanjutan dari penelitian ini tiga atau empat bulan ke depan untuk menilai apakah pembiasaan dengan penggunaan model dan metode pembelajaran tertentu memiliki signifikansi yang besar terhadap peningkatan kemampuan penguasaan kosakata siswa.

\section{KESIMPULAN}

Berdasarkan paparan hasil penelitian dan pembahasan, dapat dirumuskan kesimpulan penelitian bahwa ada peningkatan kemampuan penguasaan kosakata melalui penerapan model pembelajaran Logan Avenue Problem Solving (LAPS) pada siswa Kelas 1-C SD Negeri Kendangsari I/276 Surabaya. Peningkatan kemampuan penguasaan kosakata melalui penerapan model pembelajaran Logan Avenue Problem Solving (LAPS) pada siswa Kelas 1-C SD Negeri Kendangsari I/276 Surabaya sebesar 21\%. Upaya peningkatan kemampuan penguasaan kosakata melalui penerapan model pembelajaran Logan Avenue Problem Solving (LAPS) dapat dijadikan acuan untuk mengadakan penelitian selanjutnya dengan sudut permasalahan berbeda atau solusi berbeda dengan permasalahan serupa. Selain itu juga dapat diimplementasikan sebagai bahan kajian bagi guru yang memiliki masalah dengan perilaku kurang terpuji siswa, khususnya siswa kelas 1 Sekolah Dasar agar dapat segera tertangani oleh karena adanya unsur terapi dan pembiasaan dalam model dan metode pembelajaran ini.

Berdasarkan simpulan hasil penelitian tersebut, peneliti memberikan saran agar seluruh pihak yang berkompeten dalam bidang pendidikan turut serta mendukung upaya guru dan sekolah untuk beradaptasi dengan sistem pembelajaran secara daring yang notabene merupakan hal yang baru diterapkan bagi siswa pada tingkat Sekolah Dasar (SD). Berbagai saran dan masukan dibutuhkan untuk mengembangkan model, metode dan strategi yang cocok diterapkan dalam pembelajaran tanpa tatap muka tersebut. 
Peningkatan Kemampuan Penguasaan Kosakata Kegiatan Sehari-hari Melalui Penerapan Model Pembelajaran Logan Avenue Problem Solving (LAPS), Masiyem

\section{UCAPAN TERIMA KASIH}

Terimakasih kami ucapkan kepada Kepala Sekolah dan Guru-guru di SDN Kendangsari I/276 Surabaya yang telah memberikan kesempatan kepada peneliti dalam melaksanakan penelitian. Tidak lupa rasa terimakasih juga kami sampaikan kepada siswa yang telah ikut berpartisipasi dalam melaksanakan penelitian ini.

\section{REFERENSI}

Banathy, Bela H. "System Inquiry and Its Aplication in Education," Handbook of Research for Educational Communications and Technology, ed. David H. Jonassen, New York: Simon and Schuster Macmillan, 1996

Buchari. 1995. Kontribusi Penguasaan Kosakata dan Penguasaan Struktur Kalimat terhadap Kemampuan Mengarang (Studi Deskriptif-Analitik pada Siswa Kelas III SMA Negeri di Kotamadya Banda Aceh). Tesis: IKIP Bandung

Burhan Nurgiyantoro. 2001. Penilaian dalan Pengajaran Bahasa dan Sastra. Yogyakarta: BPFE

Darmiyati Zuchdi. (1995). Strategi Meningkatkan Kemampuan Membaca Peningkatan Pemahaman Bacaan. Yogyakarta: FPBS IKIP.

Depdiknas. 2000. Kamus Besar Bahasa Indonesia edisi Ketiga. Jakarta: Balai Pustaka

Djiwandono, Soenardi. 2008. Tes Bahasa Pegangan Bagi Pengajar Bahasa. Jakarta: PT Macanan Jaya Cemerlang

Kridalaksana, Harimurti. 1993. Kamus Linguistik Edisi Ketiga. Jakarta: Gramedia Pustaka Utama Sanjaya. 2010. Strategi Pembelajaran Berorientasi Standar Proses. Jakarta: Kencana Prenada Media Group.

Santrock, J.W. 2014. Life-span Development (13 th Ed.) University of Texas, Dallas: Mc Graw-Hill Supriyadi. 2005. Penelitian Tindakan Kelas. Bandung: Rosda Karya Sudjana, Nana. (2006). Penilaian Hasil Proses Belajar Mengajar. Bandung: PT. Ramaja Rosdakarya Suyoto. 2003. Pengaruh Kemampuan merespon Tuturan Guru dan Kemampuan Berpikir Verbal Siswa SD Terhadap Kemampuan Berbicaranya. Tesis:PPS UNNES.

Tarigan. 1993. Berbicara sebagai suatu Keterampilan Berbahasa. Bandung: Angkasa Badudu Tarigan, Henry Guntur. 1991. Metodologi Pengajaran Bahasa. Bandung: Angkasa. 